\title{
Dr. Kuldeep Singh Goleria: A True Karma Yogi
}

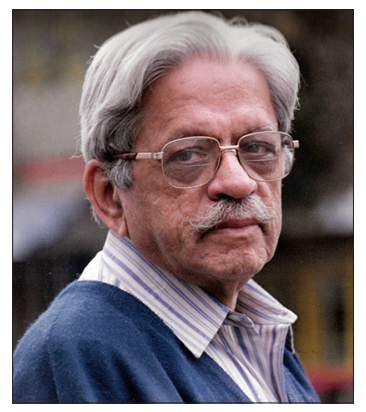

Dr. Kuldeep Singh Goleria,

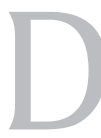

r. Kuldeep Singh Goleria was born on September 22,1931 , in Lucknow. He started his education in Kanya Kubj Intercollege, Lucknow (1937-1942), which continued in Dr. Antonio De'Silva School, erstwhile Bombay after his family shifted in 1942. He completed his intercollege in 1949 from Elphinstone College. After completing MBBS at T. N. Medical College and BYL Nair Hospital in 1949, he worked as a house surgeon for 2 years at Nair Hospital. He then moved to England to pursue FRCS. He worked as a clinical assistant at the ENT department in St. James Balham Hospital London, and then moved on to working in Plastic Surgery at Rooksdown House at Basingstoke Hospital after a strong recommendation from his chief Dr. A. B. Alexander. He thus began his journey in the field of plastic surgery under the tutelage of Sir Harold Gillies. He not only picked up the unique trilogy of 'thinking', 'creativity', and 'planning' from Sir Harold Gillies but also followed the same with the addition of his fourth quality of 'hard work'. In 1958, he obtained his FRCS at Edinburg and returned to India. He joined Nair hospital as an honorary assistant professor of Surgery. In 1962, he was selected as an honorary assistant professor in the newly established Plastic Surgery department at Seth G. S. Medical College and KEM Hospital, Mumbai, under the leadership of Dr. Charles Pinto and guidance of Dr. Eric Peet [Figure 1]. After Dr. Pinto's demise in 1970, Dr. Goleria headed the department and continued to head it for the next 19 years until his superannuation in 1989.

\begin{tabular}{|l|l|}
\hline \multicolumn{2}{|c|}{ Access this article online } \\
\hline Quick Response Code: & Website: \\
& www.ijps.org \\
\cline { 2 - 2 } & Dol: \\
\hline
\end{tabular}

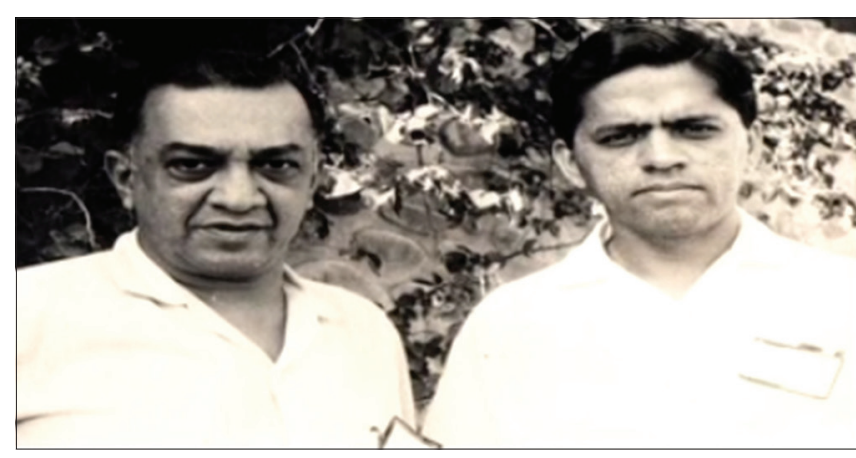

Figure 1: Dr. Goleria with Dr. Pinto in 1965

Fascinated by the work of Dr. Paul Tessier on craniofacial surgery and Dr. O' Brian on Microvascular Surgery, he decided to establish these specialities in the department. He was the pioneer of craniofacial surgery in India. He did a lot of pioneering work in the field of Plastic Surgery and vascular malformation was one of them. He published a book on 'The Management of Hemangiomas and Vascular malformations of Head and Neck' in 2011. The concept of 'Hole-In-One' technique of simultaneous cleft lip and palate repair was started as a response to socioeconomic needs. As an M. Ch. examiner to various universities, he had the reputation for being a fair and kind examiner. He loved his students like his children and had a wonderful relationship with them. He retired from KEM Hospital in 1989 and from then on continued his tryst with craniofacial surgery at Jaslok Hospital at Mumbai.

Dr. Goleria presided over APSICON in Aurangabad in 1986. The present bylaws of APSI were drafted by him. Subsequently, he served the Association as an executive

This is an open access article distributed under the terms of the Creative Commons Attribution-NonCommercial-ShareAlike 3.0 License, which allows others to remix, tweak, and build upon the work non-commercially, as long as the author is credited and the new creations are licensed under the identical terms.

For reprints contact: reprints@medknow.com

How to cite this article: Puri V. Dr. Kuldeep Singh Goleria: A True Karma Yogi. Indian J Plast Surg 2017;50:228-9. 
trustee and later on as the chairman of the board of trustees.

Dr. Goleria had a strong sense of responsibility towards the socioeconomically weaker sections and he initiated many activities with other like-minded individuals towards their benefit-in 1964 the Ramakrishna mission hospital at Khar, Mumbai; in 1968, the Shushrusha Citizen's Co-Op. Hospital the first of its kind in Asia at Dadar, Mumbai; from 1987 the free Plastic Surgery camp organised by the Lions Club Dharamsala which continued for the next 20 years. In 2008, while celebrating the $50^{\text {th }}$ anniversary of His Holiness, Dalai Lama coming to exile capital of Tibet (Dharamsala), Dr. Goleria was honoured by H. H. Dalai Lama [Figure 2].

His practice of Plastic Surgery was stamped with his zeal, dedication and planning for executing these surgeries. Dr. Goleria's personality and contribution can be only summed up in the Sanskrit adage "Yogaha Karmasu Kaushalyam” (Excellence in Action is Yoga).

\section{Financial support and sponsorship}

Nil.

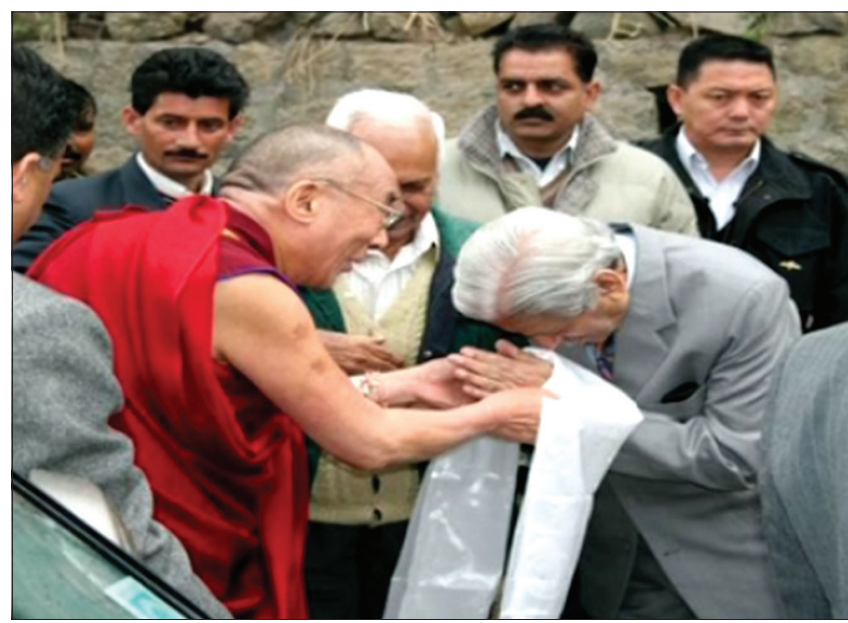

Figure 2: Being felicitated by His Holiness Dalai Lama in 2008

\section{Conflicts of interest}

There are no conflicts of interest.

Vinita Puri

Department of Plastic Surgery, Seth GS Medical College and KEM Hospital, Mumbai, Maharashtra, India

Address for correspondence: Prof. Vinita Puri, Department of Plastic Surgery, Seth GS Medical College and KEM Hospital, Mumbai, Maharashtra, India. E-mail: vp@kem.edu 